\title{
Traditional Education: Methods and Finality in Chinua Achebe's Things Fall Apart (1958) and Arrow of God (1969)
}

\author{
Babacar DIAKHATÉ \\ Laboratoire d'Études africaines et postcoloniales, Université Cheikh Anta Diop Dakar, Sénégal \\ diakhatebabacar83@hotmail.fr
}

\begin{abstract}
Before colonization, Africans had their own ways and methods of education. Its finality was to educate their children in accordance with African values. In Things Fall Apart and Arrow of God, Chinua Achebe shows that African traditional education plays a key role in the passage from childhood to adulthood. Instead of using western materials and tools such as classrooms, blackboards, talks and or pens, in African traditional education the fireplaces, the farms, storytelling, tales and proverbs were the methods and means that African wise people adopted to educate their children.
\end{abstract}

Keywords

tradition education; childhood; adulthood; values; African realities

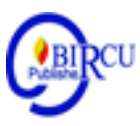

\section{Introduction}

In Things Fall Apart and Arrow of God Achebe displays that African traditional system of education was adapted to a specific social group, clan and environment. This article pinpoints the African traditional education as a system of knowledge. It also shows the role it plays to meet the expectations of a group or clan for a harmonious cultural and social development.

The first part focuses on the social status of elders as "teachers" in the community. The second section lays emphasis on how traditional education contributes to the stabilization of different social groups or clans. The final part will be the analysis of other methods of education such as initiation rites, etc.

\section{Review of Literatures}

\subsection{Elders as Educators or "Teachers"}

The elders or teachers are those whose social status as parents allow to educate their children. In Things Fall Apart, Okonkwo and his wife behave as if they were "teachers" to Ikemefuna and Nwoye and to Ezinma. However, the two characters have different ways and approaches. In Africa men are most of the time in charge of the education of the boys and women educate their daughters. Okonkwo educates Ezinma. As he teaches: "Sit like a woman!" Okonkwo said to her. Ezinma brought her two legs together and stretched them in front of her" (Achebe, 1958:32). Whenever Okonkwo has the opportunity to teach to Ezinma, he behaves like a teacher or a schoolmaster. But his wife Ekwefi is in charge of Ezinma's education.

In Thing Fall Apart, the social roles played by the elders such as Uchendo and Ogbuefi, and Ezeulu in Arrow of God must be praised. These old people are the depositary of African wisdom. Whenever they meet to settle a social problem, they give moral lessons and teach history to their children. On such occasions Ogbuefi Ezeulu tells about the punishment for someone who breaks the peace in Umuofia. He tells: 
It has not always been so. My father told me that he had been told that in the past a man who broke the peace was dragged on the ground through the village until he died. But after a while this custom was stopped because it spoilt the peace which it was meant to preserve (Achebe, 1958:23-4).

Old people used to gather around the fire and tell histories to the younger generation. The speech of the old man was a speech of wisdom. The role of the community as agent or character is essential. African traditional families consisted of Father, mother, uncles, aunts, sisters and brothers. These members of family contribute to the education of the child.

\subsection{Social Justice as an Example of Traditional Education}

Achebe demonstrates that black Africans had their own ways of establishing peace between distinct communities that were susceptible to get in conflict. This social justice permits the two belligerent communities or persons to solve their problems. Things Fall Apart by Chinua Achebe unveils traditional strategies to settle ethnic crises. In the conflict between Umuofia and Mbaino communities, while everyone in Umuofia expects to respond violently to the murder of a woman from their village, the village elders settle the problem by proposing two choices to Mbaino village. Either Mbaino village sends a man and a young virgin as compensation or a war is declared. Senghor puts:

La personne peut être offensée, et parfois les circonstances nous empêchent toute riposte efficace. Nous n'avons plus alors qu'une solution: Abandonner notre souffle vital pour sauver notre vie personnelle, notre âme (Senghor, 277-279).

The philosophy of communal life or "togetherness" was sacred in traditional Africa. Ogbuefi Ezeugo was a powerful orator and was always chosen to speak on such occasions...'Umuofia kwenu", he bellowed a fifth time, and the crowd yelled in answer. And then suddenly like one possessed in he shot out his left hand and pointed in the direction of Mbaino, and said through gleaming white teeth firmly clenched: " Those sons of wild animals have dared to murder a daughter of Umuofia (Achebe, 1958:8).

The human agents as "teachers" consist of elders, aunties, uncles, brothers and sisters and the "community characters". They contribute to the education of the African children whenever the occasion demands. The elders are the most important people or agents of the African traditional education. The attitude of Ogbuefi in the clan is very praiseworthy. Okonkwo's uncle, Uchendu, is one of the greatest educators in the community. He welcomes him when he exiles in Mbanta. He delivers:

It is Okonkwo that I primarily wish to speak to. But I want all of you to note that I am going to say... One of the commonest names we give our children is Nneka, or 'mother is supreme'. We all know that a man is the head of the family and his wives do his bidding...And yet we say Nneka 'Mother is supreme' Why is that? It's true that a child belongs to its father. But when a father beats his child, it seeks sympathy in its mother's hut. A man belongs to his father land when things are good and life is sweet. But when there is sorrow and bitterness he finds refuge in his motherland... (Achebe, 1958:93-94). 
Uchendu is a "teacher" who informs readers of the social organization of the Ibgo society. He shows the important place of uncles who stand as mother figure. Whenever the nephews are in difficulty, they find refuge in their mothers' families.

In Arrow of God, Ezeulu, the priest of Ulu is among the human agents of traditional African education. He takes part in the education of their children. Ezeulu teaches the children moral lessons and gives them important advice. When the war between his village, Umuaro and his neighboring village, Okperi is about to break, he declares: One day, five years ago, when the leaders of Umuaro decided to send an emissary to Okperi with white clay for peace or new palm frond for war, Ezeulu spoke in vain. He told the men of Umuaro that Ulu would not fight an unjust war (Achebe, 1969: 15). Ezeulu's speeches is a true moral lesson. He is always listened to, his words become reality.

In No Longer At Ease, western-type of education predominates. Indeed, there are the manifestations of daily education. Obi Okonkwo's mother teaches Agnes:

"Agnes! Agnes!

I have always said that your head is not correct. How often must I tell you to call a child by name before waking him up? Don't you know, Obi took up, pretending great anger that if you pull him up suddenly his soul may not be able to get back to his body before he wakes?'(Achebe, 1978:56).

Despite his long sojourn in Western countries, Obi Okonkwo, contributes and plays his role in the African traditional education. Moreover, Obi Okonkwo and his mother are also members of human agents of traditional African education. Noticeably, every member of the community behaves like a teacher. An elder and the other human agents participate in the education of African children. The quality of the education delivered to the young generation is adequate. Ezinma's little sister, Obiageli is a young girl who gives moral lessons. She reminds her that it is not good to speak while eating. She says: "Father...'people should not talk when they are eating or pepper may go down the wrong way" (Achebe, 1958:32). Even though Obiageli is a young girl, she gives a moral lesson about eating and speaking.

\subsection{The Education in the "fireplaces"}

If western-type education is done in classrooms with physical materials such as rulers, blackboards and chalks, African traditional education system is done wide in the open. The lack of these materials does not prevent Africans from educating their children in accordance with African values.

In Things Fall Apart, the fireplaces are considered as "classrooms" to educate girls. Boys were educated in the farms. The grandmothers and grandfathers got together around the fireplaces when the wind of the cold harmattan was blowing. They told folk tales full of moral lessons. The fireplace was where young girls were taught how to cook. Ekwefi teaches her daughter, Ezinma how to cook:

“...Ekwefi and her only daughter, Ezunma, sat near the fire place waiting

for the water in the pot to boil...Ezinma, who had joined in plucking the

feathers...put a few live coals into a piece of broken pot and Ezinma

carried it across the clean -swept compound to Nweye's mother...(

Achebe, 1958:28-29).

African traditional means of education was efficient with its good educationists or "teachers" such as Ekwefi, her aunt and Nwoye's mother who asserts: "you will blow your eyes out ... use the fan ...Ezinma's fire was now sending up thick clouds of smoke...She went on fanning it until it burst into flames (Achebe, 1958:48). 
Boys are educated in farms. They are taught how to sow yam and how to prepare the seeds of the next raining season. The process of boys' teaching of sowing yams is called "the king of crops". Instead of using "physical materials" and "schools", Africans had fireplaces and farms to teach their children. Achebe shows:

So Okonkwo encouraged the boys to sit with him in his Obi and told them stories of then land-masculine stories of violence and blood -shed. Nnoye knew that is right to be masculine and be violent...and so he feigned that he no longer cared for women's stories. And when he did this he saw that his father was pleased, and no longer rebuked him or beat him. So Nnoye and Ikemefuna would listen to Okonkwo's stories about tribal wars... (Achebe, 1958:48).

The stories told by Nwoye's mother show the presence of oral literature in the traditional education in Africa. They contribute to the performance of Ezinma, Obiageli and many other girls in Umuofia.

This oral literature also shapes the African traditional consciousness. The work songs must be dealt with. Mostly, they are used by workers such as cultural singers, weavers, fishers, farmers or even when women are washing up. These different social class workers sing while working to lose track of time. Noticeably, in ordinary activities, each occupation has its proper song that workers use to get rid of the fatigue. Geneviève asserts :

L'apprentissage de certaines activités familières peut aller de pair avec celui de la littérature orale: Ainsi les petites filles dogons apprennent de leur mère à la fois la cuisine et les jeunes garçons Sorko partant à la pêche avec leur père ou leur oncle qui leur enseigne les devinettes. (Griaule, 1967:243-248).

In some African communities or ethnics, riddles and proverbs are nocturnal exchanges between elders and boys. Sometimes, boys only can create occasions to exchange riddles. This traditional session requires a certain level of intelligence. The speaker gives rapid questions and the audience gives a quick answer. They can be mistaken by carelessness. Any slow reply is a sign of ignorance. Therefore he or she fails.

\section{Discussion}

\subsection{Education through Initiation Rites}

The initiation rites are important means and methods for African tradition education. Okonkwo choses to initiate his sons in the Ozo society: Then Okonkwo would show his wealth by initiating his sons in the Ozo society. Only the really great men in the clan were able to do this...He had five other sons and he would bring them up in the way of the clan (Achebe, 1958: 121).

In some clans or groups, the uncircumcised boy is not respected. He cannot get married. He cannot go to war to defend his nation. The uncircumcised boy is forced to stay at home to take care of the house and women. He can never have sexual intercourse. In many African communities, having children is of paramount importance of the culture. Before having sons, the boys must be circumcised. Circumcision is a "school of life" where all the circumcised are taught to respect the elders who are the depositary of wisdom. They are also taught to behave as warriors. Moreover, they are inculcated the sense of citizenship. In African polygamous families, the circumcised is taught how to behave with his parents-in-laws. 
In Les Soleils des Indépendances, Ahmadou Kourouma informs his daughter of the courageous ritual of circumcision that she is subjected to:

$\mathrm{Tu}$ verras ma fille: pendant un mois tu vivras en recluse avec d'autres excisées, et au milieu des chants, on vous enseignera tous les tabous de la tribu. L'excision est la rupture, elle démarque, elle met fin aux années d'équivoque, d'impureté de jeune fille, et après elle vient la vie de femme... (Kourouma, 1970: 32-36).

Kourouma wants his daughter to be a respectable woman in the future. Whatever his love for Salimata, his father abides by the rituals. If she is not circumcised, a girl cannot marry. She is unable to fulfill one of purposes in life, which is having children. In Les Soleils des Indépendances when the return of the brave, courageous and clean women is announced, the pride of the mothers whose daughters have been circumcised overwhelms the village. Kourouma describes :

$\mathrm{Ah}$ ! Le retour, mais il faut le savoir, c'etait la plus belle phase de l'excision. Les tam-tams, les chants et tout le village se ruant à la rencontre des filles excisées jouant les rondelles de calebasses (Kourouma, $1970: 32-36$ ).

\subsection{Education through Proverbs and Tales}

In traditional Africa, tales and proverbs played an important role as far as the education of her children is concerned. These tales and proverbs were considered as means of education. They had moral connotations. The children could draw moral lessons from them. In Things Fall Apart, Achebe introduces the tale between Ear and Mosquito. The tale teaches that it is not good to humiliate the weak creatures. He tells:

Mosquito had asked Ear to marry him, whereupon, Ear fell on the floor in uncontrollable laughter. 'How much longer do you you will live?' She asked 'you are already a skeleton.' Mosquito went away humiliated, and any time he passed her way he told Ear that he was still alive ( Achebe, 1958:53).

Many tales have meanings and try to explain the sense of the world. The tale about Ear and Mosquito teaches the reason why mosquito go wailing on man's ear only.

African proverbs are considered as truth. Most Africans inherit them from generation to generation. They are sometimes rhetorical devices to help the "dénouement" of tales. As Collins: Le proverbe, souvent n'est que l'aboutissement d'un conte, le résultat donné de portée générale qui vient clore les péripéties d'une histoire. On accède alors pleinement au domaine de la sagesse. (Colin, 1965: 76-77). In Everything Good Will Come, Sefi Atta explains that a proverb plays the same role as the palm oil plays in a meal. Proverbs make easy the understanding of a text in the same manner as palm oil makes the meal easily to be swallowed.

\section{Conclusion}

African traditional education was very organized. Even though it was considered as informal, its methods and means were very efficient. They contributed to the social and cultural formation of Africa's children. In Things Fall Apart and Arrow of God, Achebe reveals how traditional education succeeds in shaping young boys and girls. The elders (the wise), parents, aunts, sisters and brothers were considered as agents of education or "teachers". Achebe postulates that traditional education plays key role as social stabilizing. 
Indeed, the social justice promoted between Umuofia and Mbaino and between Okperi and Umuaro people respectively in Things Fall Apart and Arrow of God is illustrative. Apart from "teachers", they resorted to other methods and means such as fireplaces, farms, initiation rites to educate the children. The finality of the education was the passage from childhood to adulthood.

\section{References}

Achebe, C. (1958). Things Fall Apart. Heinemann.

Achebe, C. (1964). Arrow of God. Anchor Books Ed.

Achebe, C. (1960). No Longer At Ease. Heinemann.

Atta, S. (2004). Everything Good Will Come, Interlink Book.

Colin, B. (1965). Littérature Africaine d'hier et de demain. Collection Afrique Univers, ADEC.

Diop, C. A. (1952). L'unité culturelle de L'Afrique noire, P. A Paris.

Griaule, C. G.(1967). La Littérature Orale, in Colloque sur l'Art Négre, Rapports : Tome I, Présence Africaine.

Kourouma, A. (1970). Les Soleils des Indépendances, Paris, Seuil, 1970.

Senghor, L. (1964). Éléments Constitutifs d'une Civilisation d'inspiration négro-africaine, liberté 1, Paris, Seuil.

Senghor, L. (1964). «Ethique Négro-africaine », dans Éléments Constitutifs...Liberté 1.

Wane, S, (2008). Reines d'Afrique et Héroïnes de la Diaspora, Serbin Editions Sépia. 